\title{
Comorbidities and co-infections in people living with HIV/AIDS
}

\author{
Comorbidades e coinfecções em pessoas vivendo com HIV/Aids
}

Comorbilidades y coinfecciones en personas que viven con VIH/SIDA

\author{
Rosângela Casas Righettoํㅜㄹ Renata Karina Reis², Lílian Andreia Fleck Reinato², Elucir Gir²
}

It is a cross-sectional study made in three clinics specialized in the care of infectious diseases in Ribeirão Preto, SP, Brazil, in order to identify the prevalence of co-infections and comorbidities in people living with HIV/AIDS. Demographic and clinical variables were analyzed from 498 medical records of patients from December, 2004 to June, 2010. Data analyzed using descriptive statistics show an average of 39.3 years of age, ranging from 17 to 71 years, with 295 (59.2\%) males. 390 comorbidities were observed (78.3\%), especially dyslipidemia 126 (25.3\%), triglycerides 68 (13.7\%), hepatitis C 68 (13.7\%), oral candidiasis 60 (12.0\%), sexually transmitted disease 57 (11.4\%) and tuberculosis 51 (10.2\%). Depending on the different comorbidities, it is considered appropriate that special strategies to monitor are planned, for the diagnosis and early intervention.

Descriptors: Morbidity; HIV; Acquired Immunodeficiency Syndrome; Anti-Retroviral Agents.

Trata-se de um estudo transversal realizado em três ambulatórios especializados no atendimento às doenças infecciosas no município de Ribeirão Preto, SP, Brasil, com o objetivo de identificar a prevalência de coinfecções e comorbidades em pessoas vivendo com HIV/Aids. Foram analisadas variáveis demográficas e clínicas de 498 prontuários de pacientes do período de dezembro/2004 a junho/2010. Os dados analisados por meio de estatística descritiva mostram média de idade de 39,3 anos, variando de 17 a 71 anos, com 295 (59,2\%) indivíduos do sexo masculino. Foram observadas 390 (78,3\%) comorbidades, destacando-se a dislipidemia 126 (25,3\%), trigliceridemia 68 (13,7\%), hepatite C 68 (13,7\%), candidíase oral 60 (12,0\%), doenças sexualmente transmissíveis 57 (11,4\%) e tuberculose 51 (10,2\%). Em função das diferentes comorbidades considera-se oportuno que sejam traçadas estratégias especiais de acompanhamento, visando o diagnóstico e intervenção precoce. Descritores: Morbidade; HIV; Síndrome da Imunodeficiência Adquirida; Antirretrovirais.

Estudio transversal realizado en tres clínicas especializadas en atención a las enfermedades infecciosas en Ribeirão Preto, SP, Brasil, con objetivo de identificar la prevalencia de coinfecciones y comorbilidades en personas que viven con VIH/SIDA. Se analizaron variables demográficas y clínicas de 498 registros médicos de pacientes de diciembre/2004 a junio/2010. Los datos analizados a través de estadística descriptiva señalaron edad promedia de 39,3 años, variándose entre 17 y 71 años, con 295 (59,2\%) individuos del sexo masculino. Fueron observadas 390 (78,3\%) comorbilidades, destacándose dislipidemia, 126 (25,3\%); triglicéridos, 68 (13,7\%); hepatitis C, 68 (13,7\%); candidiasis oral, 60 (12,0\%); enfermedad de transmisión sexual, 57 (11,4\%); y tuberculosis, 51 (10,2\%). En función de las diferentes comorbilidades, se considera oportuno que estrategias especiales de acompañamiento sean desarrolladas, para diagnóstico e intervención tempranos.

Descriptores: Morbilidad; VIH; Síndrome de Inmunodeficiencia Adquirida; Antirretrovirales.

${ }^{1}$ Hospital das Clínicas, Universidade de São Paulo. São Paulo, SP, Brazil.

${ }^{2}$ Escola de Enfermagem de Ribeirão Preto, Universidade de São Paulo. Ribeirão Preto, SP, Brazil.

Corresponding author: Elucir Gir

Avenida dos Bandeirantes, 3.900, Monte Alegre. CEP: 14.040-902. Escola de Enfermagem de Ribeirão Preto, Universidade de São Paulo. Ribeirão Preto, SP, Brazil. E-mail: egir@eerp.usp.br 


\section{Introduction}

With the use of high power antiretroviral therapy, from de 90s on, the infection caused by the Human Immunodeficiency Virus (HIV) started to be considered a chronical condition, capable of control, which resulted in the improvement of the indicators of morbidity with the reduction of opportunist diseases, mortality associated to AIDS and quality of life of people who live with HIV/AIDS (PLHA) in Brazil. On the other hand, longevity contributed for the occurrence of other diseases, whether by the prolonged effect of therapy and the experience with the toxicity of the medicine or by the occurrence of comorbidities and/ or viral variants resistant to the treatment ${ }^{(1)}$.

After the beginning of the antiretroviral therapy for those infected patients, a clinical and immunological improvement is expected, besides the virus suppression, however, other manifestations can be observed, especially in the first three months, such as the Immune Reconstitution Inflammatory Syndrome, hyper-sensibility to drugs or opportunist infections, and these can be originated in some latent infection or in some new infection ${ }^{(2)}$.

The subjects infected by HIV present a higher risk for the development of cardiovascular diseases, due to the high prevalence of cardiovascular risk factors and metabolic alterations concerning the use of antiretroviral therapy, besides the systemic immune activation which provokes endothelial inflammation and atherosclerosis ${ }^{(3)}$.

In the first six years of use of antiretroviral drugs there was an increase in the rates of Kaposi's sarcoma and lymphoma in PLHA, particularly the ones which presented a low number of T-CD4 cells, while other types of cancer, especially the ones concerning the human Papillomavirus presented an average of $7 \%$ a year between 1 and 10 years $^{(4)}$.

The infection due to HIV/AIDS and the use of the antiretroviral therapy predisposes the patient to some comorbidities, such as those related to the increase of triglycerides, low density lipoproteins, and cholesterol, as well as the development of resistance to insulin which can lead to cardiovascular diseases and to the increase of the incidence of atherosclerosis, therefore aggravating the clinical condition of the bearer ${ }^{(5-7)}$.

Lipodystrophy, characterized by the loss of peripheral subcutaneous adipose tissue (face, limbs, and gluteus), accumulation of visceral fat ${ }^{(7)}$ can occur in some HIV-1 bearers under the use of antiretroviral drugs.

The presence of infection by the virus of hepatitis $\mathrm{C}$ in patients who live with HIV/AIDS was pointed as the precursor of the moderate increase of cardiovascular diseases, thus suggesting the initial treatment of the virus of the hepatitis $\mathrm{C}^{(8)}$.

Together with the introduction of new drugs in the treatment of the infection by HIV, there was the occurrence of several comorbidities which need to be early diagnosed and treated, aiming at the improvement of the health and of the quality of life of those people, as well as to the reduction of the mortality.

Facing the possibilities of the development of comorbidities and the possible exposition to new infections, especially due to immunological conditions, the following question is made: 'Which comorbidities and co-infections attack people living with HIV/AIDS who are under clinical assistance in the specialized services in the county of Ribeirão Preto, SP?

To know these comorbidities and co-infections will allow a joint reflection with the multidisciplinary health team so that specific measures of early identification can be constantly planned, implemented and evaluated. And also, to accelerate the assistance and access of the PLHA to the adequate management of the potential risk factors, such as triglycerides, hyperglycemia and hypertension, providing early intervention.

For such, this study was aimed at identifying the prevalence of comorbidities and co-infections and the profile of the people living with HIV/AIDS under clinical assistance in the services of reference in the countryside of São Paulo, Brazil. 


\section{Method}

It is a cross-sectional, descriptive and quantitative study made in three units of reference for the assistance of people living with HIV/AIDS in the county of Ribeirão Preto, SP, Brazil. All the medical records $(n=498)$ of the registered PLHA, from December 2004 to June 2010, and who were under clinical assistance were included; there were no losses and/or exclusion.

The data collection was made in all the 498 medical records of registered patients being assisted in a clinic of the units of study during the first semester of 2010, through a doctor's appointment and a careful reading of the medical records and the data obtained were transcript to a specific instrument, previously elaborated and validated regarding the title and contents, by three judges specialized in this thematic.

The variables selected for the study were related to the demographic profile (age and sex) and clinical data (number of T-CD4 cells, viral load, antiretroviral therapy, comorbidity and co-infection).

For the data analysis, the relative and absolute frequency after the organization of the variables in the Microsoft Office Excel 2007 spreadsheets was analyzed, and the processing was analyzed through the software Statistical Package for the Social Sciences (version 15.0 for Windows).

The Committee of Ethics and Research of the Nursing School of Ribeirão Preto of the Universidade de São Paulo analyzed and approved the present research, under Legal Opinion no. 0913/2008. The exemption of the Free Informed Consent Form was asked for and granted by the City Council Health Department and the Coordination of the Program of Sexually Transmissible Diseases and AIDS in the county of Ribeirão Preto.

\section{Results}

Of the $498(100 \%)$ medical records of the registered PLHA under clinical assistance, 295 (59.2\%) of the male sex and 203 (40.8\%) of the female sex were found, with an average age of 39.3 years, ranging from 17 to 71 years.

Concerning the results of the examinations of number of T-CD4 lymphocytes, $44.9 \%$ of the registers had lymphocytes below 500 cells $/ \mathrm{mm}^{3}$, with a variation of the T-CD4 cells rate between 4 and 1,662 cells $/ \mathrm{mm}^{3}$, resulting in an average of 463 cells $/ \mathrm{mm}^{3}$ (standard deviation of 280). The counting of viral load ranged from 49 to 882,160 copies $/ \mathrm{ml}$, resulting in an average of 21,225 copies/ml (standard deviation of 61,521).

47 different registered antiretroviral treatment plans were observed, including the Reverse Transcriptase Inhibitor (NRT), Protease Inhibitor (PI) and Fusion Inhibitor (FI), 361 (71.5\%) patients used some plan, being 23 plans with three medicine, 18 plans with for and 6 plans with five.

The most frequently used plans were: AZT (zidovudine) + 3TC (lamivudine) + EFV (efavirenz) in $158(43.8 \%)$ patients; AZT + 3TC + NEV (nelfinavir) in 25 (6.9\%); AZT + 3TC + LPV/r (lopinavir) in $24(6.6 \%) ; \mathrm{AZT}+3 \mathrm{TC}+\mathrm{LPV} / \mathrm{r}+\mathrm{RTV}$ (ritonavir) in 15 (4.1\%); and AZT + 3TC + ATV (atazanavir) + RTV in 11 (3.0\%) patients.

Among the 498 medical records analyzed, 390 (78.3\%) presented some kind of comorbidity, highlighting the most prevalent: dyslipidemia 126 (25.3\%), triglycerides 68 (13.7\%) and lipodystrophy 43 (8.6\%). It is highlighted that some patients presented more than one comorbidity during the period analyzed according to Table 1.

Table 1 - Distribution of comorbidities of the 498 people living with HIV/AIDS

\begin{tabular}{lc}
\hline Comorbidities & n (\%) \\
\hline Dyslipidemia & $126(25.3)$ \\
Triglycerides & $68(13.7)$ \\
Lipodystrophy & $43(8.6)$ \\
Hyperglycemia & $33(6.6)$ \\
Anemia & $20(4.0)$ \\
Others & $42(8.4)$ \\
\hline
\end{tabular}


Another significant concern is related to the infectious diseases which are commonly identified in the PLHA with some frequency in this study, the following ones were highlighted: oral and esophageal candidiasis, hepatitis $\mathrm{C}$ and the sexually transmissible diseases, among others, according to the data in Table 2.

Table 2 - Distribution of the co-infections of the 498 people living with HIV/AIDS

\begin{tabular}{lr}
\hline Co-infection & n (\%) \\
\hline Oral and Esophageal Candidiasis & $78(15.7)$ \\
Hepatitis C & $68(13.7)$ \\
Sexually Transmissible Diseases & $57(11.4)$ \\
Herpes zoster & $51(10.2)$ \\
Tuberculosis & $51(10.2)$ \\
Human Papillomavirus & $49(9.8)$ \\
Scabious & $25(5.0)$ \\
Onychomycosis & $25(5.0)$ \\
Pneumonia & $21(4.2)$ \\
Genital Herpes & $19(3.8)$ \\
Lip Herpes & $17(3.4)$ \\
Hepatitis B & $16(3.2)$ \\
Genital Candidiasis & $14(2.8)$ \\
Pneumocystis & $10(2.0)$ \\
Neurotoxoplasmosis & $10(2.0)$ \\
\hline
\end{tabular}

The fungal co-infection, manifested by oral and eshopageal candidiasis, represented 78 (15.7\%) of the diagnosed infectious diseases.

Regarding the HIV co-infection and Hepatitis C (HCV), 68 (13.7\%) patients co-infected by those viruses were noticed, whereas the sexually transmissible diseases represented 57 (11.4\%) of the registered co-infections.

It was also noticed the prevalence of $10.2 \%$ of the patients co-infected by HIV and tuberculosis, the same percentage was registered for the co-infection HIV/Herpes zoster. The prevalence of the co-infection HIV/Human Papillomavirus was 9.8\% among the medical registers of PLHA analyzed.

Other infections identified were scabious and onychomycosis representing each one of them 5.0\% of the infections, besides pneumonia, genital and lip herpes, hepatitis B (HBV), genital candidiasis, pneumocystis and neurotoxoplasmosis, summing up $21.5 \%$ of the co-infections registered in the medical records analyzed.

\section{Discussion}

In the first six months of 2014, 9,913 (65.6\%) cases of AIDS were notified in Brazil with subjects of the male sex and age range above 20 years, and 5,204 $(34.4 \%)$ of the female sex and the same age range ${ }^{(9)}$, which can be compared to the data found in this study regarding the greater prevalence among the notified cases of the male sex under clinical assistance at the researched venues.

As an innovation for the control of the transmission of HIV, Brazil implanted the treatment through prevention in December 2013, which recommends the immediate start of the antiretroviral therapy for all the PLHA, independently of the number of T-CD4 lymphocytes, respecting the motivation of the patients $^{(10-11)}$.

Despite the unquestionable positive effect of the use of antiretroviral drugs in the reduction of the mortality related to HIV, an improvement of the prognosis and an increase in the lifespan, new problems emerged related to the use of such therapeutic, once the occurrence of metabolic alterations implies in the increase of cardiovascular risk factors ${ }^{(12)}$. In this study the cardiovascular diseases were not found maybe because they are generally related to death.

Different regimes of antiretroviral therapy showed several alterations in the lipid metabolism; indinavir and lopinavir, are associated with hypercholesterolemia and hypertriglyceridemia. Didanosine, stavudine and zidovudine, induced lipoatrophy and hypertriglyceridemia, there was an increase of cardiovascular risk with the use of the abacavir ${ }^{(13)}$. Dyslipidemia was commonly registered after the use of stavudine, zidovudine, abacavir, efavirenz and some transcriptase inhibitors ${ }^{(3)}$. 
Concerning co-infections, it is highlighted that the high frequency of the sexually transmissible diseases in HIV bearers makes the transmission of the virus through ulcers and inflammation of genitalia easy. Differently from the present study, a research identified prevalence of these diseases in $87.0 \%$ of the women living with $\mathrm{HIV}^{(14)}$.

The impact of the co-infection HIV/Hepatitis C is worrisome, a study reported the prevalence of the anti-HCV in bearers of HIV in $4.1 \%$ of the participants, being more representative among men, having as risk factors the use of injected drugs ${ }^{(15)}$. Commonly the co-infection between hepatitis C and HIV, can progress more quickly to a chronical hepatic disease such as fibrosis and cirrhosis ${ }^{(16)}$.

According to the data of state of São Paulo, 46,969 cases of viral hepatitis were notified from 2007 to 2010, of those 1,318 (2.8\%) presented co-infection HIV/HBV. Concerning the virus of hepatitis C, the co-infection was observed in 3,032 (6.0\%) of the cases notified $^{(17)}$.

Tuberculosis is one the main causes of death among PLHA, which requires the implementation of more effective actions, such as the promotion of knowledge and available treatment aiming at minimizing the stigma which involves the disease, stimulating the people to look for specialized services for the early diagnosis and adequate treatment in co-infected patients $^{(18)}$.

A study made in the countryside of São Paulo, submitted to HIV serology, 307 patients enrolled in the program of tuberculosis, in the years 2010 and 2011, showing a prevalence of co-infection in $27.7 \%{ }^{(19)}$, relatively higher when compared to the one in this study (10.2\%).

With this, it is highlighted that the health professionals who assist PLHA must prioritize the control of tuberculosis, as well as those who act in the specific program, should of aware to the investigation of HIV in those patients under their assistance ${ }^{(20)}$.
The co-infection HIV/Human papillomavirus can be a precursor of lesions in the anal region, characterizing a risk factor for carcinoma in that region $^{(21)}$. And the low number of T-CD4 is shown as a factor associated to high incidence of lymphomas and cancers related to $\mathrm{HPV}^{(4)}$.

A study made in the northeast of Brazil identified the prevalence of $46.5 \%$ of infection by HPV in women who live with HIV and their age was below 35 years, time of diagnosis shorter than 24 months, more than three sexual partners and number of T-CD4 below 200cells $/ \mathrm{mm}^{3(22)}$.

Despite the advancement obtained in almost three decades of epidemic treatments, improvement in the quality of life and prognosis, AIDS is still an1 incurable disease, which needs specific care and strategies involving patients and health professionals. In this sense, it is considered evident the need of assistance by a multidisciplinary team for this population, aiming at an assistance which provides prevention and early identification of comorbidities and co-infections, as well as their clinical and psychological management.

Studies which analyze the comorbidities in PLHA contribute for the services and the teams to become organized offering assistance of quality to this population, assisting their needs both in the general as in the individual scope.

The presence of the nurse in the clinic and the importance of the diagnosis for PLHA, aiming at a plan of effective care, which considers the bio-psycho-physiological, emotional and social aspects have a repercussion in their quality of life during the antiretroviral therapy ${ }^{(23)}$.

Assistance of planned nursing, with interdisciplinary approach, turned to the promotion of health, improvement of the social and health conditions can contribute for the control of the transmission of tuberculosis and HIV, as well as the 'morbidity/mortality related to the co-infection'(24:370). 


\section{Conclusion}

The study reported diversity in the prevalence of comorbidities and co-infections which attack the PLHA in the population studied, highlighting the infections with available prevention, such as tuberculosis and hepatitis B, besides all the others which would have the occurrence decreased with the use of contraceptives.

The results highlighted the high prevalence of comorbidities among the PLHA, and the most frequent ones $(57.1 \%)$ were related to metabolic alterations and the distribution of body fat observed by dyslipidemia, hyperglycemia and lipodystrophy.

The importance of the knowledge concerning the early diagnosis of HIV for the immediate start of the antiretroviral therapy is highlighted, in the attempt to minimize the complications resulting from antiretroviral drugs and to improve the immunological condition of the PLHA, which can contribute to control co-infections.

The stigma and the impact of the social consequences related to the comorbidities and co-infections can be reduced, once the following issues are given importance: access to the information through the means of communication, schools and educative interventions for the community related to the knowledge of the transmission of the HIV and its treatment, with programs of continued education in health turned to the improvement of the level of knowledge in all the population as a way to improve the access of the people to the services of health.

Interventions and educative campaigns to increase the consciousness of PLHA of their comorbidities with culturally adequate information must be developed, implemented and evaluated.

Further studies can investigate the relation between the multiple comorbidities and co-infections, the consciousness of PLHA and their adhesion to the proposed treatment.

Although they are important sources of research, the use of secondary data is considered a limita- tion of the study, once it is possible to find variables with lack of information or unfilled domains.

\section{Acknowledgments}

To Programa Institucional de Bolsas de Iniciação Científica and the Conselho Nacional de Desenvolvimento Científico e Tecnológico for financing.

\section{Collaborations}

Righetto RC contributed in the planning of the Project, data collection and interpretations. Reis RK contributed in the analysis and interpretation of the data. Reinato LAF contributed in the writing and elaboration of the article. Gir E contributed in all stages of the project. All the authors participated in the critical revision of the data, writing and final approval of the manuscript.

\section{References}

1. Ministério da Saúde (BR). Secretaria de Vigilância em Saúde, Departamento de DST, AIDS e Hepatites virais. Boletim Epidemiológico AIDS/DST. Ano I, no 01 , até semana epidemiológica $52^{\text {a }}$ - dezembro de 2012. Brasília: Ministério da Saúde; 2012.

2. Ministério da Saúde (BR). Secretaria de Vigilância em Saúde, Departamento de DST, AIDS e Hepatites virais. Protocolo clínico e diretrizes terapêuticas para hepatite viral c e coinfecções. Brasília: Ministério da Saúde; 2011.

3. Hemkens LG, Bucher HC. HIV infection and cardiovascular disease. Eur Heart J. 2014; 35(21):1373-81.

4. Yanik EL, Napravnik S, Cole SR, Achenbach CJ, Gopal S, Olshan A, et al. Incidence and timing of cancer in HIV-infected individuals following initiation of combination antiretroviral therapy. Clin Infect Dis. 2013; 57(5):756-64.

5. Vellozzi C, Brooks JT, Bush TJ, Conley LJ, Henry $\mathrm{K}$, Carpenter CC, et al. The study to understand the natural history of HIV and AIDS in the era of effective therapy (SUN Study). Am J Epidemiol. 2009; 169(5):642-52. 
6. Almeida SEM, Borges M, Fiegenbaum M, Nunes CC, Rossetti MLR. Metabolic changes associated with antiretroviral therapy in HIV-positive patients. Rev Saúde Pública. 2009; 43(2):283-90.

7. Villarroya F, Domingo P, Giralt M. Drug-induced lipotoxicity: lipodystrophy associated with HIV-1 infection and antirretroviral treatment. Biochim Biophys Acta. 2010; 1801(3):392-9.

8. Gillis J, Smieja M, Cescon A, Rourke SB, Burchell AN, Cooper C, et al. Risk of cardiovascular disease associated with HCV and HBV coinfection among antiretroviral-treated HIV-infected individuals. Antiviral Ther. 2014; 19(3):309-17.

9. Ministério da Saúde (BR). Secretaria de Vigilância em Saúde. Departamento de DST, AIDS e Hepatites virais. Boletim Epidemiológico AIDS/DST. Ano III, no $01,27^{\text {a }}$ à $52^{\text {a }}$ semanas epidemiológicas julho a dezembro de 2013, 01 a $26^{\mathrm{a}}$ semanas epidemiológicas - janeiro a junho de 2014. Brasília: Ministério da Saúde; 2014.

10. Ministério da Saúde (BR). Secretaria de Vigilância em Saúde. Departamento de DST, Aids e Hepatites Virais. Protocolo Clínico e Diretrizes Terapêuticas para Manejo da Infecção pelo HIV em Adultos. Brasília: Ministério da Saúde; 2013.

11. Govindasamy D, Kranzer K, Ford N. Strengthening the HIV cascade to ensure an effective future ART response in sub-Saharan Africa. Trans R Soc Trop Med Hyg. 2014; 108:1-3.

12. Pupulin ART, Carvalho PG, Nishi L, Nakamura CV, Guilherme ALF. Enteropatógenos relacionados à diarreia em pacientes HIV que fazem uso de terapia anti-retroviral. Rev Soc Bras Med Trop. 2009; 42(5):551-5.

13. Souza SJ, Luzia LA, Santos SS, Rondó PHC. Lipid profile of $\mathrm{HIV}$-infected patients in relation to antiretroviral therapy: a review. Rev Assoc Med Bras. 2013; 59(2):186-98.

14. Duarte MTC, Parada CMGL, Souza LR. Vulnerability of women living with HIV/aids. Rev Latino-Am Enfermagem. 2014; 22(1):68-75.

15. Carvalho FHP, Côelho MRCD, Vilella TAS, Silva JLA, Melo HRL. HIV/HCV coinfection at an university hospital in Recife, Brazil. Rev Saúde Pública. 2009; 41(1):133-9.
16. Antonello VS, Tovo CV, Kliemann DA, Santos BR, Zaltron VF. Uso do escore APRI na avaliação de doença hepática, após início de terapia antirretroviral, em pacientes portadores do HIV co-infectados com HCV versus monoinfectados por HIV. Rev Soc Bras Med Trop. 2010; 43(6):678-81.

17. Farias N, Souza I, Coelho DM, Oliveira UB, Binelli CA. Coinfecção pelos vírus das hepatites $\mathrm{B}$ ou $\mathrm{C}$ e da imunodeficiência adquirida: estudo exploratório no Estado de São Paulo, Brasil, 2007 a 2010. Epidemiol Serv Saúde. 2012; 21(3):475-86.

18. Rodrigues ILA, Monteiro LL, Pacheco RHB, Silva SED. Abandonment of tuberculosis treatment among patinets co-infected with TB/HIV. Rev Esc Enferm USP. 2010; 44(2):383-7.

19. Castrighini CC, Reis RK, Neves LAS, Galvão MTG, Gir E. Epidemiological profile of HIV/tuberculosis co-infection in a city in the state of São Paulo, Brazil. J Antivir Antiretrovir. 2013; 5(5):119-22.

20. Siqueira KZ, Mendonça SA, Penedo CC. Indicação da prova tuberculínica e infecção latente da tuberculose em HIV-positivos, Município de Blumenau, Estado de Santa Catarina, Brasil, 20042009. Epidemiol Serv Saúde. 2012; 21(4):635-44.

21. Crum-Cianflone N, Hullsiek KH, Marconi V, Weintrob A, Ganesan A, Barthel V, et al. Trends in the Incidence of Cancers among HIV-Infected Persons and the Impact of Antiretroviral Therapy: A 20-Year Cohort Study. AIDS. 2009; 23(1):41-50.

22. Martins AES, Lucena-Silva N, Garcia RG, Welkovic S, Barboza A, Menezes MLB, et al. Prevalence of human papillomavirus infection, distribution of viral types and risk factors in cervical samples from human immunodeficiency virus-positive women attending three human immunodeficiency virus-acquired immune deficiency syndrome reference centres in northeastern Brazil. Mem Inst Oswaldo Cruz. 2014; 109(6):738-47.

23. Brasileiro ME, Cunha LC. Diagnósticos de enfermagem em pessoas acometidas pela síndrome da imunodeficiência adquirida em terapia antirretroviral. Rev Enferm UERJ. 2011; 19(3):392-6.

24. Lemos LA, Feijão AR, Galvão MTG. Social and health aspects of patients co-infected with HIV/ tuberculosis. Rev Rene. 2013; 14(2):364-71. 